\title{
IAMJ
}

INTERNATIONAL

AYURVEDIC

MEDICAL JOURNAL

\section{AYURVEDIC MANAGEMENT OF KITIBH KUSHTHA (SCALP PSORIASIS) - A CASE REPORT}

\author{
Sanika R. Pandit ${ }^{1}$, Rajesh Kolarkar ${ }^{2}$ \\ ${ }^{1}$ P.G. Scholar Ayurved Samhita and Siddhanta Department, Y.M.T. Ayurvedic College, Kharghar, \\ Maharashtra, India \\ ${ }^{2}$ Professor and HOD Ayurved Samhita and Siddhanta Department, Y.M.T. Ayurvedic College, Kharghar, \\ Maharashtra, India
}

Corresponding Author: sanu9rp@gmail.com

https://doi.org/10.46607/iamj4209122021

(Published Online: December 2021)

Open Access

(C) International Ayurvedic Medical Journal, India

Article Received: 26/11//2021 - Peer Reviewed: 10/12/2021 - Accepted for Publication 11/12/2021

\begin{abstract}
People suffering from Autoimmune diseases is increasing day by day. The exact cause of the autoimmune disease is still unknown. Psoriasis is one such disease. Dry thick raised itchy patches on the skin are the sign of psoriasis. They are covered with silvery-white scales. It is triggered by infection stress and cold. There is no known cure but with proper management, serious flares can be avoided. It generally affects the scalp, sole, palm, elbows and knees. Such diseases can be effectively managed by Ayurveda. Ayurveda defines the majority of skin diseases under the category of Kushtha. Clinically we can compare scalp psoriasis to Kitibha Kushtha mentioned in the granthas. In the present study, a 53-year-old male patient was treated for scalp psoriasis. He presented himself with itching, dry scales, flake formation and whitish-pink patches on the scalp. He was treated with Arogyavardhini, Sukshma Triphala, Panchatikta Ghrut, Jatamansi choorna internally and Karanja Tel for local application. The treatment was given for seven months. The case report is presented here to share effective management of scalp psoriasis by Ayurveda.
\end{abstract}

Keywords: Psoriasis, Kitibha Kushtha, autoimmune diseases, Arogyavardhini, Ayurveda.

\section{INTRODUCTION}

Autoimmune diseases are a heterogeneous group of more than 80 chronic conditions which affect about
7 to $10 \%$ of the worldwide population ${ }^{1}$. In Autoimmune disease, the immune system tends to de- 
stroy one's own cells for reasons unknown. Psoriasis is one such disease. [Psoriasis is a chronic inflammatory skin disease with a strong genetic predisposition and autoimmune pathogenic traits The worldwide prevalence is about $2 \%$ but varies according to regions $]^{2}$. The estimated incidence of scalp psoriasis among psoriatic patients is 45 to $56 \%{ }^{3}$. Hence it is the need of the day to find managing techniques for such widely occurring diseases. There is no such cure as of now which completely cures psoriasis. Steroids and Immunosuppressants temporarily manage the symptoms. But on exposure to triggering factors, it flares up. However, it can be effectively managed with the help of Ayurveda. The intensity and severity of the disease can be reduced considerably. Lifestyle modification is also necessary along with Ayurvedic treatment. Ayurveda focuses on treating the root cause of the disease instead of just managing the symptoms. As per Ayurveda, the symptoms of psoriasis can be compared to that of Kitibha Kushtha. Kitibha Kush- tha is described as grey coloured, rough to touch and tough. It is included in Kshudra Kushtha by Charak. It is Vaat Kaph dominant skin disease ${ }^{4}$. Here in this case of scalp psoriasis focus is on treating the vitiated kaph and Vaat dosh along with pitta Virechan (purgation) which are the root cause of the disease.

The Case Report is as follows - A 53 old Male Patient visited OPD on 18/04/2021.

Chief complaints were -

1. Severe Itching in Scalp region. (Kandu)

2. Flake Formation (Whitish Pink)

3. Silvery white scales (Twak Sphutana)

The patient was suffering from the above problems for two years. He visited a dermatologist who diagnosed it as scalp psoriasis and steroids were prescribed for treatment. No significant relief was observed. The patient is a known case of DM and Hypertension for a few years and is on Istamet 50/500 and Telma 40 once daily.

\section{Personal History}

\begin{tabular}{|l|l|l|}
\hline Name - XYZ & Age -53 years & Sex - Male \\
\hline Marital status - Married & Occupation - Job & Diet - Veg Non-Veg Mix \\
\hline Addiction - None & Sleep - Adequate & Appetite - Good \\
\hline Pulse $-80 / \mathrm{min}$ & BP $-130 / 80 \mathrm{~mm} \mathrm{Hg}$ & Weight $-67 \mathrm{Kg}$ \\
\hline G.C. - Fair & Temperature - Afebrile & \\
\hline
\end{tabular}

\section{Ashtavidh Pariksha -}

\begin{tabular}{l|l} 
Nadi-Pittapradhan Vaat & Shabda - Spashta \\
\hline Mal-Prakrut (Normal) & Sparsha - Anushna \\
\hline Mutra - Prakrut (Normal) & Druk - Drushtimandya \\
\hline Jeevha - Niraam & Akruti - Madhyam
\end{tabular}

\section{Local Examination -}

1. Whitish pink scales along the hairline on the scalp.

2. Redness post itching.

3. Flaking.

\section{Hetu (Causes) -}

1. Aaharaj [ Excessive Non-Veg (Fish), spicy salty food, Viruddhashan (Incompatible food)]

2. Stress

3. Poor Hygiene.

\section{Lakshana (Clinical Features) -}

1. Kandu (Itching)

2. Twak Sphutana (Flake Formation)

Vyaadhi Vinishchay (Diagnosis)- Scalp Psoriasis (Kitibha Kushtha), Dosh - Kaph pradhaan Vaat, Dushya - Rasa Rakta

Treatment Principle -

1. Doshaghna Chikitsa (Kapha vaataghna)

2. Mrudu Virechan (Purgation) for Twak Shuddhi. 


\section{Treatment Given -}

\begin{tabular}{|l|l|l|l|}
\hline Medicine & Dose & Route & Anupaan \\
\hline Arogyavardhini & $500 \mathrm{mg}$ twice a day & Oral & With water \\
\hline Sukshma Triphala & $500 \mathrm{mg}$ twice a day & Oral & With water \\
\hline Panchatikta Ghrut & $10 \mathrm{ml}$ in the morning & Oral & With water \\
\hline Jatamansi Churna & $3 \mathrm{gm}$ at night & Oral & With water \\
\hline $\begin{array}{l}\text { Karanja oil (Oil of } \\
\text { Pongamia Glabra) }\end{array}$ & Apply twice a day & Local Application & - \\
\hline
\end{tabular}

Duration -7 months., Follow Up - Every 4 weeks.

Pathyaapathya (Dietary and Lifestyle modification)

1. The patient was advised to avoid Nonveg food especially fish, excessive oily, spicy and salty foods since they all cause Raktadushti as per Ayurveda.
2. Management of stress since it is the triggering factor for Psoriasis.

3. Maintain Personal Hygiene.

4. Lifestyle modification - Waking up early and sleeping early; No daytime sleeping; Regular exercises and Yoga to be done.

\begin{tabular}{|c|}
\hline Pathya \\
\hline 1) Regular Home-made food \\
\hline 2) All types of fruits except oranges and sweet lime \\
\hline 3) Koshna Jal \\
\hline 4) All types of vegetables except tomato \\
\hline
\end{tabular}

Pathya

Apathya

1) Curd

2) Nonveg especially fish

3) Chaat items; Fast food

4) tomato; Tamarind chutney

5) Chips; wafers, pickle.

Grading criteria for assessment -

\begin{tabular}{|l|l|l|l|l}
\hline Clinical Feature & Grade 0 & Grade 1 & Grade 2 & Grade 3 \\
\hline 1) Kandu (Itching) & Absent & Mild & Moderate & Severe \\
\hline 2)Twak Sphutana (Flaking) & Absent & Mild & Moderate & Severe
\end{tabular}

PASI scale -0.7 , Observation and Results- Assessment of patient was done as per the grading criteria during every follow up after 4 weeks.

\begin{tabular}{|l|l|l|l|l|l|l|l|}
\hline \multirow{2}{*}{ Clinical Feature } & Before Treatment & \multicolumn{2}{|l|}{ After Treatment } \\
\cline { 2 - 7 } & $18 / 04 / 2021$. & $18 / 05 / 21$ & $18 / 06 / 21$ & $18 / 07 / 21$ & $18 / 08 / 21$ & $18 / 09 / 21$ & $18 / 10 / 21$ \\
\hline Kandu (Itching) & 3 & 2 & 2 & 1 & 1 & 1 & 0 \\
\hline Twak Sphutana (Flaking) & 3 & 2 & 2 & 2 & 1 & 1 & 0 \\
\hline
\end{tabular}

Pasi Scale Score reduced to 0.1., Significant relief in signs and symptoms.

\section{DISCUSSION}

Kitibha Kushtha (Psoriasis) is a kapha vaataj dominant disease. Rasa and Rakta Dushti are present. Recurrence is possible and hence it is difficult to treat. In the present treatment, highly significant relief was observed in Kandu (itching). It may be because of Ushna Veerya and Kapha Vaataghna properties of the medicines given. Also, no adverse drug effect was observed. Kandu is because of viti- ated Kapha Dosh while Twak Sphutana is because of vitiated Vaat Dosh. The medicines used in this treatment have properties of Jantughna, Krumighna, mrudu rechan, kandughna and Kushthaghna. Hence, they can reduce kushtha. Oil has a greater absorption in the skin and hence for local application Karanja oil was given.

The probable action of medicines is as follows -

1. Arogyavardhini- It acts as on Vaat and Kapha Dosh by its ushna gun and absorbs the kled (moisture) from the stomach and does pitta Virechan (brings out excess and dushti pitta). 
2. Sukshma Triphala- It acts as Jantughna (antimicrobial) and does kled absorption by its Ruksha gun.

4. Panchatikta Ghrut- It brings out the excess pitta by Mrudu Virechan (soft laxative) and thus balances the pitta dosh.

5. Jatamansi Choorna - It helps to calm down the mind and helps relieve stress.

6. Karanja oil- Oil of Pongamia Glabra used as anti-pruritic and anti-microbial.

\section{CONCLUSION}

Kitibha Kushtha is one of the commonly found skin diseases. It clinically co-relates with scalp psoriasis. The present case study signifies that despite advanced technologies in medical science, this disease is not curable. However, Ayurvedic Treatment along with lifestyle modification is highly effective in the management of Kitibha Kushtha (Scalp Psoriasis).

\section{CONSENT}

Written informed consent was obtained from the patient for the presentation of this case report.

Source of Support - NIL

Conflict of Interest - None declared.

\section{REFERENCES}

1. Aaron Lerner, Patricia Jeremias, Torsen Matthias, "The World Incidence and prevalence of Autoimmune diseases is increasing." International Journal of Coeliac disease, Vol.3 no.4 (2015): 151155.doi:10.12691/ijcd-3-4-8.

2. Adriana Rendon and Knut Schakel, "Psoriasis Pathogenesis and Treatment". International Journal of molecular sciences.2019 March 23. doi:10.3390/ijms20061475.

3. Klaudia Dopytalska, Piotr Sobolewski, Irena Walecka, "Psoriasis in special localizations", Reumatologia.2018;56(6):392-398. Published online 2018 Dec 23.doi: 10.5114/reum.2018.80718.

4. Yadavji Trikamji Acharya, editor Charak Samhita with Ayurved Deepika commentary of Chakrapani, Chikitsasthan chapter 7 Kushtha Chikitsitam, Reprint edition 2013, Chaukhamba Publications, Varanasi, 221001, India.
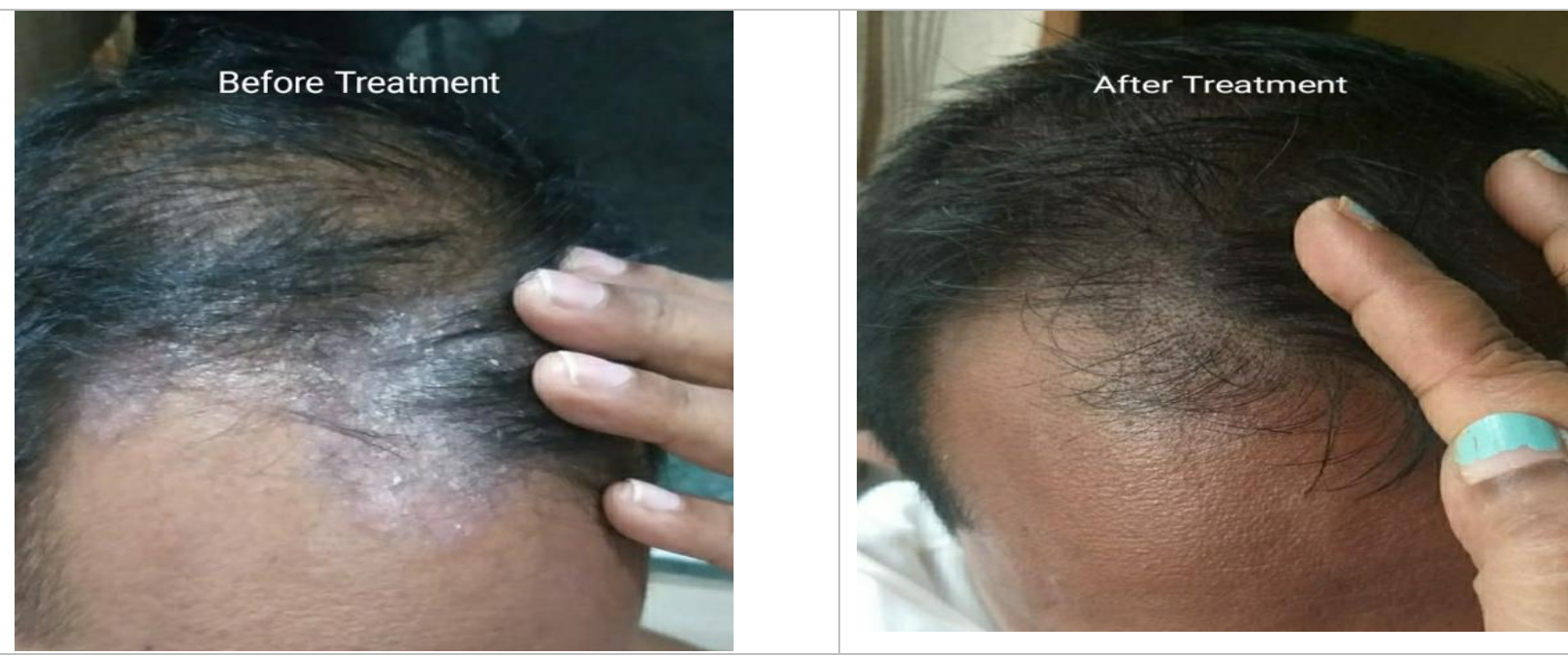

\section{Source of Support: Nil Conflict of Interest: None Declared}

How to cite this URL: Sanika R. Pandit Rajesh Kolarkar: Ayurvedic Management Of Kitibh Kushtha (Scalp Psoriasis) - A Case Report. International Ayurvedic Medical Journal \{online\} 2021 \{cited December 2021\} Available from: http://www.iamj.in/posts/images/upload/3179_3182.pdf 